\title{
Chapter 7 \\ What Do Pāsifika Students in New \\ Zealand Value Most for Their \\ Mathematics Learning?
}

\author{
Julia Hill, Jodie Hunter and Roberta Hunter
}

\begin{abstract}
Achieving equity for all mathematical learners is an urgent challenge for educators. Within New Zealand, Pāsifika students are at a much greater risk of underachievement than students from other ethnic groups (Caygill et al. in TIMSS 2015: New Zealand Year 5 Maths results. Comparative Education Research Unit, Ministry of Education, Wellington, 2016a; Caygill et al. in TIMSS 2015: New Zealand Year 9 Maths results. Comparative Education Research Unit, Ministry of Education, Wellington, 2016b). In this chapter, we examine and explore the mathematics educational values of middle school Pāsifika students in New Zealand based on their significance in contributing to more effective and equitable mathematics learning. Drawing on survey responses and individual interviews with 131 Year Seven and Eight Pāsifika students, we highlight the most frequently espoused mathematics educational values as utility, peer collaboration/group-work, effort/practice, and family/familial support. Results from this study provide insight into what is valued by Pāsifika students and the types of classroom culture and pedagogy which could be developed to align with these students' values. The wider implications of the study address the need for educators to examine the mathematics educational values of minority students in order to provide equitable mathematics classrooms.
\end{abstract}

Keywords Mathematics educational values $\cdot$ Equity $\cdot$ Middle years $\cdot$ Pāsifika

J. Hill · J. Hunter $(\varangle) \cdot$ R. Hunter

Institute of Education, Massey University Albany, Private Bag 109204,

Auckland, New Zealand

e-mail: j.hunter1@ massey.ac.nz

J. Hill

e-mail: juliaLhill@gmail.com

R. Hunter

e-mail: r.hunter@massey.ac.nz

(C) The Author(s) 2019

P. Clarkson et al. (eds.), Values and Valuing in Mathematics Education,

ICME-13 Monographs, https://doi.org/10.1007/978-3-030-16892-6_7 


\subsection{Introduction}

Both in New Zealand and internationally, achieving equity for all mathematical learners is an urgent challenge for educators. New Zealand classrooms, like those in many other countries are becoming increasingly diverse. Pāsifika peoples are a fast growing population with the proportion of Pāsifika ${ }^{1}$ students in New Zealand schools doubling over the past decade (Ministry of Education (MoE) 2006a). Pāsifika describes a multi-ethnic group of indigenous peoples from Pacific Island nations, including both those who were born in New Zealand and those who have migrated from the Pacific Islands. This group identifies themselves with the islands and/or cultures of the Cook Islands, Samoa, Tonga, Tokelau, Niue, Fiji, Tuvalu, and the Solomon Islands (Coxon et al. 2002).

Currently, New Zealand has one of the largest mathematical achievement gaps related to ethnicity across developed countries, with Pāsifika students in New Zealand at a much greater risk of underachievement (Education Assessment Research Unit and New Zealand Council for Educational Research 2015; Caygill et al. 2016a, b). Disruption of these trends are required if equitable outcomes are to be achieved. We argue that culturally responsive mathematics experiences, that is, recognition and use of students' cultural capital in all aspects of teaching and learning (e.g., see Gay 2010; Ladson-Billings 1994) has the potential to enhance equitable outcomes for Pāsifika students. A body of research studies (e.g., Civil and R. Hunter 2015; J. Hunter et al. in press) show improved equitable educational outcomes can be achieved when we attend to Pāsifika culture and values in the classroom. However, there appear to be limited research studies which specifically explore the mathematics educational values of Pāsifika students in New Zealand mathematics classrooms.

We define values as the fundamental "convictions which an individual has internalised as being the things of importance and worth" (Seah and Andersson 2015, p. 169) which act as "general guides to behaviour or as points of reference in decisionmaking or the evaluation of beliefs or actions" (Halstead 1996, p. 5). Mathematics educational values relate specifically to mathematics learning and pedagogy. They take place in the context of activities and decisions that are made to enhance the learning and teaching of mathematics (Bishop 1996). These values can influence student preference for types of learning activities and pedagogy used within the classroom. They are also highly sensitive to cultural influences and can vary depending on the culture of the learner (Barkatsas and Seah 2015). The authors of this chapter chose to focus on mathematics educational values based on the contribution of these values to more effective and equitable mathematics learning for Pāsifika learners, a minority group within New Zealand. Specifically, we explore the following research questions, firstly: What are the most important mathematics educational values espoused by Pāsifika learners in New Zealand classrooms? Secondly, what are the wider implications of investigating the mathematics educational values of minority students for countries with diverse cultural groups within their educational systems?

\footnotetext{
1 'Pāsifika' are a multi-ethnic group of indigenous peoples from the Pacific Islands, see page 2 and 3.
} 


\subsection{Pāsifika Peoples and Valuing}

The Pāsifika Education Plan (MoE 2013) is a policy document that was developed by the New Zealand Ministry of Education to highlight the strategic direction planned to improve Pāsifika education outcomes in New Zealand. It covers both the compulsory education sectors as well as early learning through to tertiary education. Within this document, the key Pāsifika cultural values are identified as respect, reciprocity, service, inclusion, spirituality, leadership, love, belonging, and family. Although there have been a number of similar policy documents over the past decade (MoE 2006b, 2009), there appears to be limited values research related to Pāsifika peoples, particularly from the perspective of the learner or self-reporting of values. While there are no studies specifically exploring the types of mathematics education values held by Pāsifika learners in New Zealand, there are several studies which provide some insight into valuing by this group of learners.

Anthony (2013) explored students' perspectives about what it meant to be a "good" mathematics teacher and student. Anthony reported that Pāsifika students valued a "good" teacher as someone who cared about his/her students, and who provided clear explanations. In terms of perceptions about a "good" student, Anthony found that these students endorsed a greater proportion of collaborative values (e.g., sharing, mathematical community, respect) than the other ethnic groups in the study. Likewise, other studies (Averill 2012; Hāwera et al. 2007; Hunter and Anthony 2011; Sharma et al. 2011) investigated Pāsifika students' perspectives on learning experiences in the mathematics classroom. These researchers affirmed that Pāsifika mathematics students often endorsed values that were reflective of their collectivist cultural values. For example, their responses indicated that the students valued respect and positive relationships with peers/teachers, reciprocity and helping others, collaboration-group-work, and family support as important for their mathematics learning.

\subsection{Methodology}

The data used within this chapter are drawn from a larger study (Hill 2017) involving a mixed methods approach. A focus was placed on the use of student voice to better understand what students identifying with four different ethnic groups (East Asian, European, Māori, and Pāsifika) in New Zealand valued as important for their mathematics learning.

The participants in the larger study were 227 middle school (Years 7 and 8) students from four state schools. However, the focus in this chapter is on 131 Pāsifika students from three schools. All of these Pāsifika students attended low socio-economic, high poverty, urban schools. These three schools had been involved in an ongoing professional development and research project entitled Developing Mathematical Inquiry Communities (DMIC) (R. Hunter et al. in press). The DMIC project is 
Table 7.1 The twelve mathematical activities/statements and their value indicators

\begin{tabular}{|c|c|}
\hline Mathematical learning activity or statement & Value indicator \\
\hline I learn more in maths by working with other children & Peer collaboration/group-work \\
\hline $\begin{array}{l}\text { Maths involves looking for different ways to find the } \\
\text { answer }\end{array}$ & Flexibility with strategies \\
\hline $\begin{array}{l}\text { It is important to respect and like my maths teacher and } \\
\text { for them to respect me }\end{array}$ & Respect \\
\hline $\begin{array}{l}\text { It is important for maths to be useful in real life or for my } \\
\text { future }\end{array}$ & Utility \\
\hline $\begin{array}{l}\text { To be good at maths I need to practice with lots of } \\
\text { questions }\end{array}$ & Effort and practice \\
\hline $\begin{array}{l}\text { I cannot be good at maths without the } \\
\text { support/love/guidance of my family }\end{array}$ & Family/familial support \\
\hline Maths needs to be clear and make sense to me & Clarity and understanding \\
\hline $\begin{array}{l}\text { It is important to talk about my ideas in a group or with } \\
\text { my partner }\end{array}$ & Peer collaboration/communication \\
\hline $\begin{array}{l}\text { If I can't solve a difficult maths problem I need to keep } \\
\text { working at it }\end{array}$ & Persistence \\
\hline It is important to feel like I belong in my maths class & Belonging \\
\hline It is important to get the correct/right answer in maths & Accuracy \\
\hline $\begin{array}{l}\text { My maths teacher needs to explain it to me properly so } \\
\text { that I understand }\end{array}$ & Teacher explanations/clarity \\
\hline
\end{tabular}

implemented in schools that serve the most disadvantaged communities in New Zealand and is a transformative re-invention of pedagogical practices designed to support teachers' development of culturally responsive teaching (Gay 2010) and ambitious mathematics pedagogy (Kazemi et al. 2009).

Middle school students were the focus of this study because it is during this critical period that many students experience a negative and detrimental affective shift, with a decline in their academic engagement (Attard 2011; Grootenboer and Marshman 2015). The students were asked to individually complete a survey where they ranked 12 mathematics educational values from most important to least important, by numbering each value from one through to twelve. All the values used in the survey were derived from research literature and policy documents (e.g., Clarkson et al. 2000; MoE 2013; Seah and Wong 2012). As children may find it difficult to relate and respond directly to particular values, each value was incorporated into a specific mathematical learning activity or statement (see Table 7.1).

For example, the statement "to be good at maths I need to practice with lots of questions" was understood to indicate the value of effort and practice in mathematics. During an individual follow-up interview, all students were asked to provide reasons for why they had selected the three most important values.

For the larger study, results from the survey were exported into Statistical Package for Social Scientists (SPSS) in order to investigate the statistical relationships among 
variables. For the findings reported in this chapter, we analysed how many students ranked each of the twelve values in their top three values to determine the degree of importance of each mathematical education value. As this is the first dedicated study into this area, more sophisticated analysis will be reported in later publications. All interview data was wholly transcribed and analysed through Nvivo software guided by a grounded theory approach in which codes, categories, patterns, and themes were developed. For example, a student response explaining why the value of collaboration/group was ranked highly was: "Because you can help other children" which was coded into the node of helping others. Another response: "They [peers] help me more, like get more confident" was coded into the node of confidence.

\subsection{Findings and Discussion}

Within this section to determine what Pāsifika students' value most in relation to mathematics educational values, we will identify the four highest ranked (that is, the most important) mathematics educational values (see Table 7.2) and explore student explanations of why they choose these values.

\subsubsection{Utility}

The statement "It is important for maths to be useful in real life or my future" was used as a value indicator for the mathematics educational value of utility. This value had the greatest proportion of students ranking it within their first three values with $47 \%(n=61 / 131)$ of the students ranking it as one of their most important values.

More than half of the students ranking this value in their top three $(n=33 / 61)$ viewed the value of utility as important for their future education or career goals. This ranged from students equating engaging in mathematics as necessary for employment: You need to be good at maths in order to get a job, to students identifying specific occupations (e.g., accountant, police officer, banker, teacher) and the role of mathematics within this career choice. Other students identified the utility of mathematics as necessary for future study: You can learn lots of maths for your future

Table 7.2 The highest ranked mathematics educational values amongst Pāsifika students

\begin{tabular}{l|l}
\hline Value & $\begin{array}{l}\text { Percentage of Pāsifika students who ranked the value in their } \\
\text { top three }(n)\end{array}$ \\
\hline Utility & $47 \%(61 / 131)$ \\
\hline Peer collaboration/group-work & $37 \%(48 / 131)$ \\
\hline Effort and practice & $24 \%(31 / 131)$ \\
\hline Family/familial support & $24 \%(31 / 131)$ \\
\hline
\end{tabular}


so that you might go to university. Alternatively, students $(n=20 / 61)$ identified the value of utility as important for everyday activities (e.g., cooking, shopping, building, money). For example, one student stated: My Mum said if I never learn maths properly I won't know how to pay bills or count money. Another student explained: Every time I go with my Mum to shopping, we always need to figure out the discounts. Interestingly, these statements suggest that utilitarian values can be influenced by the values held by parents and caregivers and also highlight the impact of out of school experiences.

Valuing utility means that these students desired mathematics which was either practical, or relevant to their own lives or the world around them. Students desired mathematics which had a purpose, that related to everyday activities, or which impacted upon their future success. Given the growing technological and digital economy (Ministry of Business Innovation and Employment 2017), there is a strong message both within New Zealand and internationally that mathematics is important for future employment and economic advancement (Gravemeijer et al. 2017). A previous study by Young-Loveridge et al. (2006) found that an overwhelming majority of students held beliefs about the importance of mathematics for the future, suggesting that utilitarian mathematics values are reflective of societal values and not necessarily distinguishable by cultural differences.

International values research studies (e.g., Barkatas and Seah 2015; Österling and Andersson 2013) also indicates the dominance of mathematical utilitarian values. For example, Österling and Andersson reported that Swedish middle school students highly valued "connecting mathematics to real life" (p. 22). Similarly, Barkatsas and Seah found the favourite mathematical tasks reported by students across Australia and several Chinese states involved real life scenarios. The strong utility values held by students both in the current study and other published research (e.g., Barkatas and Seah 2015; Österling and Andersson 2013) reaffirms the need for mathematics teachers to provide authentic learning experiences with opportunities for students from all cultural groups to apply concepts and skills to real life scenarios.

\subsubsection{Peer Collaboration/Group-Work}

To investigate the mathematics educational value of peer collaboration/group-work, the statement "I learn more in maths by working with other children" was used. Thirty-seven percent ( $n=48 / 131$ ) of students ranked this statement within their top three values.

In the follow-up interview, it appeared that there was a link between this mathematics education value and a key Pāsifika cultural value of reciprocity. Students viewed collaboration and group-work as providing reciprocal learning opportunities: Because we learn more with each other. Many students $(n=34 / 48)$ referred to the benefits of gaining new knowledge and learning new strategies from their peers as well as having their own errors highlighted. For example, one student explained: So you can get different strategies, another stated: Because if I get something wrong, 
they will correct me. Conversely, a smaller group of students $(n=8 / 48)$ also spoke of the opportunity they had themselves to help others. For example, one student explained: So when they are stuck I can help them. These types of explanations can also be linked to the cultural value of service as identified in the Pāsifika Education Plan (MoE 2013).

Collaboration is a core collectivist cultural value for Pāsifika people (MoE 2013). In this study, Pāsifika students valued group work because sharing ideas and strategies helped the students to progress and improve their own mathematics. Earlier research by Sharma et al. (2011) found that Pāsifika students recognised the benefit of collaborative mathematical learning both for building their own mathematical understanding and progressing their peers' mathematical understanding. Similarly, Anthony (2013) found that Pāsifika students valued a social arrangement in the classroom, which suited their collaborative ways of learning. This contrasts with research from Asia (e.g., Law et al. 2011; Zhang et al. 2016) which demonstrated an absence of collaborative mathematics values from East Asian students, and also research from Sweden (Seah and Peng 2012) that highlighted Swedish middle school students valuing independent working due to their perception that listening to their peers' conflicting strategies was confusing rather than helpful.

\subsubsection{Effort/Practice}

The mathematics educational value of effort/practice was explored through the statement: "To be good at maths I need to practice with lots of questions". This statement was ranked in the first three values of $24 \%(n=31 / 131)$ of the students.

The key reason that students $(n=19 / 31)$ provided for the choice of this value indicated they viewed effort and practice as a way of facilitating their progress and achievement. Several students used the phrase "practice makes perfect" in relation to their mathematical learning. Specifically, a student stated: If you practice you will get better and better. Other students $(n=6 / 31)$ viewed this value as important as they saw effort and practice as a means of developing their conceptual understanding and clarity: So you can understand the problems. A small group of students $(n=4)$ linked the value of effort/practice to their future goals and success for education and employment. For example, one student stated: So I don't have to struggle when it comes to a test or when I am in college, another student explained: So you can learn and you can get a better job.

These responses indicated that students' perceived success and understanding in mathematics was achieved through hard work and practice. The results of the current study with Pāsifika students are broadly consistent with other values research from Europe and Asia (Lee and Seah 2015; Lim 2015; Österling and Andersson 2013) where students were reported to value effort and practice for their mathematics learning. This finding has important implications in challenging ongoing deficit perceptions and low expectations that many New Zealand teachers have towards their Pāsifika students (Rubie-Davies 2009, 2016). For example, Turner et al. (2015) 
revealed New Zealand teacher expectations were highest for Asian and Pākehā (European) mathematics students, and lowest for Pāsifika and Māori, with one teacher in their study expressing that Pāsifika students were less likely to achieve in mathematics because they "are very lazy and they do not spend enough time studying and learning" (p. 62).

\subsubsection{Family/Familial Support}

The statement "I cannot be good at maths without the support, love or guidance of my whānau/family" was used as a value indicator for the mathematics educational value of family/familial support. Twenty-four percent of students $(n=31 / 131)$ ranked this statement in their first three values.

Most commonly, students $(n=17 / 31)$ described how their family (including extended family such as grandparents, or aunties and uncles) assisted with homework or taught them new skills or strategies. For example, a student stated: If you have homework and you don't know how to do the strategy, then you can just ask your family. The other key theme from the students $(n=10 / 31)$ for the reason of the importance of this value was the role of family in providing encouragement and support: Every time I fail in maths, my Mum always encourages me to carry on and try my best.

For these students, it was important that their family was actively involved in their mathematics learning. This finding is aligned to previous general education studies (e.g., Hannant 2013; J. Hunter et al. 2016) which found that values concerning family are central to the identity of Pāsifika learners with Pāsifika students frequently citing family as a major driver of their motivation and achievement. In the current study, the Pāsifika students valued their family as important for their mathematics learning because the family provided support with homework and learning along with encouragement. There has been limited mathematics education research investigating Pāsifika students' valuing of family support. The current finding is important to counteract the inaccurate stereotypes held by many New Zealand teachers relating to Pāsifika parents, that is that Pāsifika parents are not interested or involved in their children's schooling (Nakhid 2003), or that parents do not have the mathematical knowledge or skills to help with their children's homework (Nicholas and Fletcher 2015; Turner et al. 2015).

\subsection{Conclusion and Implications}

This study aimed to determine what Pāsifika students valued as most important for their mathematics learning. We discovered that Pāsifika students' valued mathematics which was useful and/or practical for the present or future, and valued effort and practice as important for success in mathematics. The commonality of these two 
values across international research studies (e.g., Barkatas and Seah 2015; Lee and Seah 2015; Lim 2015; Österling and Andersson 2013) suggests these mathematics educational values are influenced by common societal and educational values.

Interestingly, while identifying some values common with international studies, the findings from the current study also identify values specific to the local community, that is Pāsifika students in New Zealand schools. These were the values of peer collaboration-group work and family/familial support. This finding aligns with earlier research (e.g., Averill 2012; J. Hunter et al. 2016; R. Hunter and Anthony 2011) demonstrating a relationship between students' culture and their values within the mathematics classroom. Importantly, this finding highlights the need for educators to investigate the mathematics educational values of students from minority cultural groups, in order to both acknowledge and build on students' cultural backgrounds in the mathematics classroom.

Acknowledging students' values has important implications for culturally responsive, equitable and effective mathematics teaching, thus, it is important that teachers recognise what is being valued in their classrooms. For example, in the current study, the valuing of opportunities for group work and collaboration indicates pedagogical approaches that educators could adopt to align with their students' mathematics educational values. Furthermore, the valuing of effort and practice by Pasifika students offers a direct challenge to teachers' deficit and stereotypical views often reported in previous studies (e.g., Rubie-Davies 2009, 2016). This highlights the need for teachers, especially teachers of minority students, to consult with and determine what their students' value prior to making assumptions. As Seah (2016) contends by recognising the cultural uniqueness of what the students' value for their mathematics learning, teachers can customise instruction/activities to align with student values.

In the New Zealand context, it appears that there has been limited research exploring students' self-reported mathematics values. The findings from the current study may provide a useful starting point for developing an evidence base in New Zealand related to Pāsifika students as well as contributing to the international mathematics values literature. As Seah (2016) writes "how do we go about facilitating students' appropriate valuing such that it helps them to study mathematics more effectively? The first step may be to have a good idea of what is currently being valued by students" (p. 4). By recognising what is valued (or not valued) in the mathematics classroom, teachers can develop classroom culture or pedagogy which aligns with the students' values or work with students to examine values which may contradict the classroom norms and pedagogy. In alignment with previous studies (e.g., J. Hunter et al. 2016; Seah et al. 2016), we argue that when values are acknowledged in the mathematics classroom, relationships are strengthened, students' cultural identities are affirmed, students become more engaged, and ultimately, mathematics learning is enhanced. 


\section{References}

Anthony, G. (2013). Student perceptions of the 'good' teacher and 'good' learner in New Zealand classrooms. In G. Anthony, B. Kaur, M. Ohtani, \& D. Clarke (Eds.), Student voice in mathematics classrooms around the world (pp. 209-225). Rotterdam, Netherlands: Sense Publishers.

Attard, C. (2011). "My favourite subject is maths. For some reason no-one really agrees with me": Student perspectives of mathematics teaching and learning in the upper primary classroom. Mathematics Education Research Journal, 23(3), 363-377.

Averill, R. (2012). Caring teaching practices in multiethnic mathematics classrooms: Attending to health and well-being. Mathematics Education Research Journal, 24(2), 105-128.

Barkatsas, T., \& Seah, W. (2015). Learners' preferred mathematical task types: The values perspective. In A. Bishop, H. Tan, \& T. Barkatsas (Eds.), Diversity in mathematics education (pp. 63-79). Cham: Springer.

Bishop, A. (1996). How should mathematics teaching in modern societies relate to cultural values-some preliminary questions. In Paper Presented at the Meeting of the Seventh Southeast Asian Conference on Mathematics Education, Hanoi, Vietnam.

Caygill, R., Hanlar, V., \& Singh, S. (2016a). TIMSS 2015: New Zealand Year 5 Maths results. Wellington: Comparative Education Research Unit, Ministry of Education.

Caygill, R., Hanlar, V., \& Singh, S. (2016b). TIMSS 2015: New Zealand Year 9 Maths results. Wellington: Comparative Education Research Unit, Ministry of Education.

Civil, M., \& Hunter, R. (2015). Participation of non-dominant students in argumentation in the mathematics classroom. Intercultural Journal, 26(4), 296-312.

Clarkson, P., Bishop, A. J., FitzSimons, G., \& Seah, W. T. (2000). Challenges and constraints in researching values. In M. Goos, R. Brown, \& K. Makar (Eds.), Proceedings of the 31 st annual conference of the Mathematics Education Research Group of Australasia (pp. 188-195). Brisbane: MERGA.

Coxon, E., Anae, M., Mara, D., Wendt-Samu, T., \& Finau, C. (2002). Literature review on Pacific education issues. Wellington: Ministry of Education.

Education Assessment Research Unit and New Zealand Council for Educational Research. (2015). National monitoring study of student achievement: Mathematics and statistics 2013. Wellington: Ministry of Education.

Gay, G. (2010). Culturally responsive teaching: Theory, research, and practice (2nd ed.). New York: Teachers College Press.

Gravemeijer, K., Stephan, M., Julie, C., Lai, F. L., \& Ohtani, M. (2017). What mathematics education may prepare students for the society of the future? International Journal of Science and Mathematics Education, 15, 105-123.

Grootenboer, P., \& Marshman, M. (2015). Mathematics, affect and learning: Middle school students' beliefs and attitudes about mathematics education. London: Springer.

Halstead, J. M. (1996). Values and values education in schools. In J. Halstead \& M. Taylor (Eds.), Values in education and education in values (pp. 3-14). London: The Falmer Press.

Hannant, B. (2013). What works: Academically successful Pāsifika males identify factors contributing to their educational outcomes (Unpublished Master's thesis). Auckland: Massey Univeristy.

Hāwera, N., Taylor, M., Young-Loveridge, J., \& Sharma, S. (2007). "Who helps me learn mathematics, and how?" Màori children's perspectives. In D. Holton (Ed.), Findings from the New Zealand Numeracy Development Projects 2006 (pp. 54-66). Wellington: Ministry of Education.

Hill, J. (2017). What do culturally diverse middle school students' value for their mathematics learning (Unpublished Master's thesis). Auckland: Massey Univeristy.

Hunter, J., Hunter, R., Bills, T., Cheung, I., Hannant, B., Kritesh, K., et al. (2016). Developing equity for Pāsifika learners within a New Zealand context: Attending to culture and values. New Zealand Journal of Educational Studies, 51(2), 197-209.

Hunter, R., \& Anthony, G. (2011). Forging mathematical relationships in inquiry-based classrooms with Pāsifika students. Journal of Urban Mathematics Education, 4(1), 98-119. 
Hunter, R., Hunter, J. \& Bills, T. (in press). Enacting culturally responsive or socially-response-able mathematics education. In C. Nicol, S. Dawson, J. Archibald \& F. Glanfield (Eds.). Living culturally responsive mathematics curriculum and pedagogy: Making a difference with/in indigenous communities. Sense.

Kazemi, E., Franke, M., \& Lampert, M. (2009). Developing pedagogies in teacher education to support novice teachers' ability to enact ambitious instruction. In. R. Hunter, B. Bicknell \& T. Burgess (Eds.), Proceedings of the 32nd Annual Conference of the Mathematics Education Research Group of Australasia (pp. 12-30). Palmerston North: MERGA.

Ladson-Billings, G. (1994). The dreamkeepers. San Francisco: Jossey-Bass Publishing.

Law, H. Y., Wong, N. Y., \& Lee, N. Y. L. (2011). The Third Wave studies of values in effective mathematics education: Developing students' mathematical autonomy in classroom learning. The Mathematics Educator, 13(1), 72-86.

Lee, H. F., \& Seah, W. T. (2015). "Math is not for us, not an indigenous thing, you know": Empowering Taiwanese indigenous learners of mathematics through the values approach. In Paper Presented at the Eight International Mathematics Education and Society Conference, Portland, OR.

Lim, C. S. (2015). Riding the third Wave: Negotiating teacher and Students'value preferences relating to effective mathematics lessons. In Paper presented at the Selected Regular Lectures from the 12th International Congress on Mathematical Education, Seoul, Korea.

Ministry of Business Innovation \& Employment. (2017). Economic development: Digital economy. Wellington: Ministry of Business Innovation \& Employment.

Ministry of Education. (2006a). Education counts: School rolls. Wellington: Ministry of Education.

Ministry of Education. (2006b). Pāsifika Education Plan 2006-2010. Wellington: Ministry of Education.

Ministry of Education. (2009). Pāsifika Education Plan 2009-2012. Wellington: Ministry of Education.

Ministry of Education. (2013). Pāsifika Education Plan 2013-2017. Wellington: Ministry of Education.

Nakhid, C. (2003). "Intercultural" perceptions, academic achievement, and the identifying process of Pacific Islands students in New Zealand schools. Journal of Negro Education, 72(3), 297-317.

Nicholas, K., \& Fletcher, J. (2015). What supports 11-to 13-year-old Pāsifika students in mathematics learning in New Zealand classrooms? Education, 45(1), 1-15.

Österling, L., \& Andersson, A. (2013). Measuring immeasurable values. In A. Lindmeier \& A. Heinze (Eds.), Proceedings of the meeting of the 37th Conference of the International Group for Psychology of Mathematics Education (pp. 17-24). Kiel: PME.

Rubie-Davies, C. (2009). Teacher expectations and labeling. In L. Saha \& A. Dworkin (Eds.), International handbook of research on teachers and teaching (pp. 695-707). Boston: Springer.

Rubie-Davies, C. (2016). High and low expectation teachers: The importance of the teacher factor. In S. Trusz \& P. Babel (Eds.), Interpersonal and intrapersonal expectancies (pp. 145-157). Abington, Oxon: Routledge.

Seah, W. T. (2016). Values in the mathematics classroom: Supporting cognitive and affective pedagogical ideas. Pedagogical Research, 1(2), 45-63.

Seah, W. T., \& Andersson, A. (2015). Valuing diversity in mathematics pedagogy through the volitional nature and alignment of values. In A. Bishop (Ed.), Diversity in mathematics education (pp. 167-183). Cham: Springer.

Seah, W. T., Andersson, A., Bishop, A., \& Clarkson, P. (2016). What would the mathematics curriculum look like if values were the focus? For the Learning of Mathematics, 36(1), 14-20.

Seah, W. T., \& Peng, A. (2012). What students outside Asia value in effective mathematics lessons: A scoping study. ZDM: The International Journal on Mathematics Education, 44(1), 71-82.

Seah, W. T., \& Wong, N. Y. (2012). What students value in effective mathematics learning: A 'Third Wave Project' research study. ZDM: The International Journal on Mathematics Education, 44(1), $33-43$. 
Sharma, S., Young-Loveridge, J., Taylor, M., \& Häwera, N. (2011). The views of Pāsifika students in New Zealand about communicating mathematically. Asia Pacific Journal of Education, 31(4), 503-519.

Turner, H., Rubie-Davies, C. M., \& Webber, M. (2015). Teacher expectations, ethnicity and the achievement gap. New Zealand Journal of Educational Studies, 50(1), 55-69.

Young-Loveridge, J., Taylor, M., Sharma, S., \& Hāwera, N. (2006). Students' perspectives on the nature of mathematics. In P. Grootenboer, R. Zevenbergen \& M. Chinnappan (Eds.), Proceedings of the 29th Annual Conference of the Mathematics Education Research Group of Australasia (pp. 583-590). Adelaide: MERGA.

Zhang, Q., Barkatsas, T., Law, H. Y., Leu, Y. C., Seah, W. T., \& Wong, N. Y. (2016). What primary students in the Chinese mainland, Hong Kong and Taiwan value in mathematics learning: A comparative analysis. International Journal of Science and Mathematics Education, 14(5), 907-924.

Open Access This chapter is licensed under the terms of the Creative Commons Attribution 4.0 International License (http://creativecommons.org/licenses/by/4.0/), which permits use, sharing, adaptation, distribution and reproduction in any medium or format, as long as you give appropriate credit to the original author(s) and the source, provide a link to the Creative Commons license and indicate if changes were made.

The images or other third party material in this chapter are included in the chapter's Creative Commons license, unless indicated otherwise in a credit line to the material. If material is not included in the chapter's Creative Commons license and your intended use is not permitted by statutory regulation or exceeds the permitted use, you will need to obtain permission directly from the copyright holder. 